\title{
Assessment of Seed and Tuber Production Potential in Varieties of Sphenostylis stenocarpa (Africa Yam Bean)
}

\author{
Dolapo Olalekan Ibirinde1 (ㄷ, Charity Onyenonachi Aremu², Kerimu Balogun ${ }^{1}$, Lola Oladokun ${ }^{3}$ \\ ${ }^{1}$ Department of Crop Production and Protection, Federal University, Wukari, Nigeria \\ ${ }^{2}$ Landmark University, Omu-Aran, Nigeria \\ ${ }^{3}$ Ladoke Akintola University of Technology, Ogbomoso, Nigeria \\ Email: lehkcan@yahoo.com, aremu.charity@lmu.edu.ng, karimubalogun@gmail.com, oladokunlola@gmail.com
}

How to cite this paper: Ibirinde, D.O., Aremu, C.O., Balogun, K. and Oladokun, L. (2019) Assessment of Seed and Tuber Production Potential in Varieties of Sphenostylis stenocarpa (Africa Yam Bean). Agricultural Sciences, 10, 870-881.

https://doi.org/10.4236/as.2019.107066

Received: May 17, 2019

Accepted: July 8, 2019

Published: July 11, 2019

Copyright $\odot 2019$ by author(s) and Scientific Research Publishing Inc. This work is licensed under the Creative Commons Attribution International License (CC BY 4.0).

http://creativecommons.org/licenses/by/4.0/

\begin{abstract}
Twenty accessions of African Yam Bean, grown at the Teaching and Research Farm of Ladoke Akintola University of Technology, Ogbomoso during the cropping seasons of May to November, 2014 and 2015 were assessed for genetic diversity and Genotype $\times$ Environment interaction effects on trait performance and their ability to produce tuber. The first six Principal Components jointly explained $70.30 \%$ of the total variation among the accessions. Vine length, branching pattern, pod number, pod length, seed number, and seed yield contributed mostly to the observed variations. Seed biometric traits were most variable and contributed $52 \%$ of total variation. Variance due to genotype accounted for $54.2 \%$, environment $10.5 \%$ and $\mathrm{G} \times \mathrm{E}$ interaction accounted for $30.1 \%$ of the interaction sum of squares. Accessions, G2, G4, G47, G49 and G50 produced tubers, while accessions G6, G15, G31, G32 and G33 nodulated extensively. Conversely, there was a marginal reduction in seed yield in accessions that either produced tubers or nodules.
\end{abstract}

\section{Keywords}

Variations, Interactions, Accessions, Diversity, Environment, African Yam Bean

\section{Introduction}

The African yam bean is specially suited to lowland conditions; though it can be grown up to $1800 \mathrm{~m}$ agro-ecology ranging from savannah to rain forest, provided there is a combination of adequate rainfall $\left(100 \mathrm{~cm}^{3}\right.$ or more during the growing season) and reasonably good drainage. In the East central state of Nige- 
ria, yam beans are usually inter planted with yams between April and June and supported on the same stakes as the yams (Okigbo [1]; GRIN [2]). The plant is cultivated in parts of Africa (Central African Republic, Zaire, East Africa and Ethiopia) for its potato like spindle-shaped tubers or for its edible seeds (Dalziel [3]). Generally, African yam bean is grown for tubers in certain areas and for seeds in other locations, with some striking evidence that yield of seeds and tubers are inversely related (Ene-Obong and Okoye [4]). The seed yield of African yam bean can be as high as $3000 \mathrm{~kg} / \mathrm{ha}$ (Dukes [5]). The average seed per plant is between 100 and $200 \mathrm{~g}$ and the tuber yield per plant is $0.5 \mathrm{~kg}$ (Anochili [6]). At Nsukka, estimated yield based on at least a mean of 100 stands of two plants each, of four cultivars, alternated with yams on $120 \mathrm{~cm}$ rows amounted to about $3025 \mathrm{~kg}$ dry seeds per hectare and $1875 \mathrm{~kg}$ fresh weight of tubers per hectare (Okigbo [1]).

African yam bean is one of the endangered African crop species that has immense advantages, especially high nutritional value required in human diet. For instance, African Yam Bean produces both seeds and tubers that are edible. Both seeds and tubers are quite rich sources of protein, carbohydrate and dietary fiber (Ajibade [7]). The African Yam Bean seed is only second to soybean in its protein content, while the tuber is also rich in carbohydrate and protein. Cropping of African Yam Bean can be seen to maximize the available land area, in the sense that, a typical African Yam Bean plant stand is capable of producing seed and tuber yield at the same time. Therefore, a plant stand serves a dual purpose of producing seeds and tubers. At present, African Yam Bean has been relegated to an unimportant underutilized crop, predominantly grown by the older generation of farmers (Saka [8]). Despite its land maximization and nutritional benefits, bulk of the genetic resources of this crop are in the hands of these farmers, with little research effort concentrated on improving upon the quantity and quality of its yield, thus threatening its survival (Ekpo [9]).

African yam bean has immense economic potentials. Besides the production of two major food substances, the value of the protein in both tubers and seeds is comparatively higher than what could be obtained from most tuberous and leguminous crops (Nwokolo [10]). The tuber of AYB has a protein content that is more than twice that obtainable in sweet potato or Irish potato (NRC [11]). It is also higher than those in yam and cassava (Amoatey [12]). Moreover, the amino acid values in AYB seeds are higher than those in pigeon pea, cowpea, and bambara groundnut, while the tubers are known to be rich in starch and protein; dry matter is approximately $35 \%$, of which starch is about $80 \%$ and protein about $14 \%$, ranging from $12.5 \%$ to $19 \%$ for six varieties (Uguru and Madukaife [13]).

Fundamentally, traits are controlled by genes and the affect of the environment influence on it, although a number of genotypes can adapt to new environments more readily than others $(\mathrm{Fu}[14])$. The phenotypic data has more polymorphism in genetic diversity and reveal genetic variations indirectly. Because it very difficult to obtain molecular data for a large number of accessions, such 
that will reflect sufficient polymorphism, to express the genetic diversity of germplasm, thus the morphological traits adjudged as most suitable and practical tools for studying the genetic diversity on large numbers of accessions. Variation in shape of plants has always been an important means of distinguishing individuals, controlling seed production, and identifying the negative traits those effects on yield (Moyib [15]).

Principal Component Analysis is a method of data reduction, to clarify the relationship between two or more characters and to divide the total variance of the original characters into a limited number of uncorrelated new variables (Wiley [16]). This will allow visualization of the differences among the individuals and identify possible groups (Mohammadi and Prasanna [17]; Aremu et al. [18]). The reduction is achieved by linear transformation of the original variables into a new set of uncorrelated variables, known as principal components (AOAC [19]). Because the principal components are orthogonal and independent of each other, each revealing different properties of the original data, and may be interpreted independently; the total variation in the original data set may be broken down into components that are cumulative (Mohammadi and Prasanna [17]). The effort of the research work is channeled towards screening for seed, tuber and seed-tuber yielding genotypes, respectively and also identification of traits that contribute majorly to seed and tuber yield in African yam bean.

\section{Materials and Methods}

\subsection{Experimental Material, Site and Layout}

Twenty accessions of African Yam Bean (TSs-10, TSs-101, TSs-111, TSs-116, TSs-118, TSs-121, TSs-125, TSs-128, TSs-137, TSs-139, TSs-148, TSs-153, TSs-154, TSs-23, TSs-349, TSs-58, TSs-89, TSs-9, TSs-93 and TSs-95), from different eco-geographical areas of Nigeria, were sourced from the germplasm unit of the International Institute of Tropical Agriculture (IITA), Ibadan, Nigeria. The research was conducted between April and November of 2014 and 2015 cropping seasons, at the Teaching and Research Farm of Ladoke Akintola University of Technology, Ogbomoso, Nigeria. The Research Farm (at longitude $4^{\circ} 10^{\prime} \mathrm{E}$, latitude $8^{\circ} 10^{\prime} \mathrm{N}$ ) is located in the Guinea Savannah Zone of Southwest Nigeria (Aremu et al., 1997). With the temperature range of $28^{\circ} \mathrm{C}$ to $33^{\circ} \mathrm{C}$ and relative humidity of about $74 \%$ all year round, the region is characterized by a bimodal rainfall distribution pattern that extends from about eight to nine months of the year. The soil of the experimental site is moderately drained, characterized by a sandy-loam texture; with wild sunflower, siam weeds, guinea grass, scattered trees and shrubs (such as neem and shear butter trees) as vegetative cover. Four replicates of the various accessions of AYB were sown out using the Randomized Complete Block Design (RCBD), giving a gross experimental area of $21 \mathrm{~m} \times 21$ $\mathrm{m}\left(441 \mathrm{~m}^{2}\right)$, which comprised of 10 beds, horizontally aligned (having dimensions of $1 \times 4 \mathrm{~m}$ ). Beds were replicated four times, thus a total of forty beds. Both the inter-row and the intra-row spacing were $1 \mathrm{~m} \times 1 \mathrm{~m}$. There were five plant 
stands per bed, and a total of two hundred (200) plant stands in the whole experimental plot. One meter $(1 \mathrm{~m})$ plot border was kept around the experimental plots.

\subsection{Data Collection and Analysis}

Data were collected on the qualitative and quantitative characters, which include growth, reproductive, seed and tuber yield traits of the African Yam Bean. These include; number of days to flowering (estimated as the period between germination and the appearance of first flower), vine length (estimated as length of vine at eight weeks after planting WAP, prior to staking), grain filling period (the onset of pod production will be used to indicate the beginning of grain filling, while the yellowing of pod indicates the cessation of the grain filling period), number of primary (vine) branches (the first set of branches, just at the base), number of secondary (vine) branches (branches developing from the primary branches), number of peduncles per plant (through hand counting), total number of pods per plant (through hand counting), pod length (measured in "cm" through the use of measuring tape), number of seeds per pod (through hand counting), weight of 100 seeds (measured in "g" through the use of sensitive scale), root form (whether root nodule or tuber), number of tubers per plant (through counting), weight of tubers per plant (estimated as the total tuber yield per plant), proximate and mineral analyses of tubers (Laboratory analysis of the tuber dry matter), by using the Kjedhal method as recorded in AOAC, 2005.

\section{Results}

\subsection{Means, Mean Square (MS) and Coefficient of Variation of Characters from 20 African Yam Bean Genotypes}

Due to the effects of the different planting seasons, there were significant differences among the characters measured, as reflected in Table 1, except for number of seed per pod, 100 seed weight, primary and secondary branches, internode distance and days to maturity. The coefficient of variation (CV) value ranged from $36.37 \%$ (for days to $50 \%$ flowering), to $98.02 \%$ (for number of seeds per pod). Very high CV values were observed for number of seeds per pod (98.02), internode distance (93.83), seed yield per plant (90.67), number of seeds per plant (95.50), number of pods per plant (93.28), primary branches (96.51), filled pods per plant (77.70), days to maturity (87.08) and number of secondary branches (91.22). Whereas quantitative characters showed very low to moderate variability. Number of peduncle (90.47), length of vine (89.79), 100-seed weight (86.48), and pod length (75.65) are coefficient of variation values recorded, above variability. Days to $50 \%$ flowering however, recorded the least variation (36.37).

\subsection{The First Six Principal Component Analyses of the 20 African Yam Bean Accessions Studied}

From Table 2, the first six principal components is seen to explain about $70.30 \%$ 
Table 1. Means, mean square (MS) and coefficient of variation of characters from 20 African yam bean accessions.

\begin{tabular}{rlccc}
\hline SN & \multicolumn{1}{c}{ Character } & Mean & Mean square & CV (\%) \\
\hline 1. & Number of peduncles & 25.43 & $16.35^{*}$ & 90.47 \\
2. & Number of pods per plant & 38.44 & $555.67^{* *}$ & 93.28 \\
3. & Filled pods per plant & 14.61 & $162.38^{* *}$ & 77.7 \\
4. & Pod length & 22.75 & $11.80^{*}$ & 75.65 \\
5. & Number of seeds per pod & 19.15 & $9735.62^{* *}$ & 98.02 \\
6. & 100 seed weight & 20.65 & 2.23 & 86.48 \\
7. & Vine length & 97.28 & $243.66^{* *}$ & 89.79 \\
8. & Primary branches & 2.57 & 0.26 & 96.51 \\
9. & Secondary branches & 6.59 & 1.58 & 91.22 \\
10. & Internode & 11.48 & $46.28^{*}$ & 93.83 \\
11. & Number of seeds per plant & 172.50 & $35405.39^{* *}$ & 95.50 \\
12. & Days to 50\% flowering & 110.22 & $71.08^{*}$ & 36.37 \\
13. & Seed yield per plant & 34.04 & $1401.32^{* *}$ & 90.67 \\
14. & Days to maturity & 151.26 & $619.69^{* *}$ & 87.08 \\
\hline
\end{tabular}

${ }^{*}, * *$ significant at 0.05 and 0.01 probability levels.

Table 2. Eigen values, proportion of variation and contribution of 22 traits to total variation in the first six principal component axes of the 20 AYB accessions studied.

\begin{tabular}{lcccccc}
\hline \multicolumn{1}{c}{ Traits } & PC1 & PC2 & PC3 & PC4 & PC5 & PC6 \\
\hline Seed yield/plant & 0.3679 & -0.1302 & 0.0819 & 0.2205 & -0.0267 & -0.0233 \\
Number of peduncles & 0.2867 & 0.2514 & -0.3278 & -0.0152 & 0.1202 & 0.2008 \\
Pods/peduncle & 0.2100 & -0.2521 & 0.1958 & -0.2311 & 0.0389 & -0.0723 \\
Pod/plant & 0.3647 & 0.0146 & -0.1355 & -0.1292 & 0.0973 & 0.0891 \\
Filled pods & 0.3850 & -0.0415 & 0.0576 & 0.0032 & 0.1817 & -0.0934 \\
Flowers/plant & 0.2897 & 0.2271 & -0.3291 & -0.0043 & 0.1064 & 0.2167 \\
Pod length & -0.0263 & -0.0664 & 0.1347 & 0.3840 & 0.3896 & 0.1609 \\
Seed/pod & -0.0050 & -0.1434 & -0.1657 & 0.3507 & -0.5466 & 0.0889 \\
100 seed weight & -0.1509 & -0.1963 & 0.0525 & 0.4438 & 0.1462 & -0.0781 \\
Days to sprouting & 0.0140 & -0.0083 & 0.0903 & 0.2302 & 0.0138 & -0.4525 \\
Vine length & 0.1568 & -0.0911 & 0.4297 & 0.0291 & -0.0101 & -0.0065 \\
Primary branches & 0.0028 & 0.5148 & 0.1643 & 0.0782 & -0.0967 & -0.1225 \\
Sec. branches & 0.0577 & 0.5328 & 0.0941 & 0.2346 & -0.0355 & -0.1930 \\
Days to 50\% flowering & -0.1848 & 0.0033 & -0.1450 & 0.3364 & 0.1997 & 0.3899 \\
Days to maturity & 0.0220 & 0.2093 & 0.3499 & 0.2277 & -0.0187 & 0.2942 \\
Internode dist. & -0.0054 & 0.2021 & -0.0307 & 0.0031 & 0.0462 & -0.4356 \\
Seeds/plant & 0.3882 & -0.0666 & 0.0536 & 0.1264 & -0.0397 & -0.0246 \\
\hline
\end{tabular}




\begin{tabular}{lcccccc} 
Continued & \multicolumn{7}{c}{} & & & \\
\hline Plant yield $(\mathrm{kg} / \mathrm{ha})$ & 0.3677 & -0.1301 & 0.0819 & 0.2205 & -0.0267 & -0.0233 \\
Seed texture & -0.0244 & 0.0234 & 0.1222 & -0.1112 & 0.6372 & -0.0844 \\
Coat colour & -0.0172 & 0.2733 & 0.2880 & -0.1302 & -0.1257 & 0.2703 \\
Mottling & 0.0088 & -0.0270 & 0.4345 & -0.1994 & -0.1114 & 0.2893 \\
Eigen value & 5.99 & 2.44 & 1.85 & 1.67 & 1.46 & 1.35 \\
Percent variation & 28.54 & 11.64 & 8.80 & 7.96 & 6.95 & 6.41 \\
Cumulative & 28.54 & 40.18 & 48.98 & 56.94 & 63.89 & 70.30 \\
\hline
\end{tabular}

of the total variation, with Eigen values ranging from 1.35 in principal component six (PC6), to 5.99 in principal component one (PC1). Seed yield traits were more prominent, accounting for more than a quarter (28.54\%) of the variations. PC2 which was largely controlled by branching pattern and seed quality accounted for $11.6 \%$. Also, PC3, controlled by maturity date and morphological traits (such as the vine length and degree of mottling) accounted for $8.80 \%$ of the total variation, while PC 4, 5 and 6 accounted for $7.69 \%, 6.95 \%$ and $6.41 \%$ of the total variations respectively.

\subsection{Principal Component Analysis}

Scores (eigen vector) of the major characteristics describing the first three principal axes are presented in Table 3. The first axis was loaded mainly by plant morphological quantitative traits of days to flowering and branching pattern, while the second principal component was loaded by seed yield and related traits, particularly pod length $(\mathrm{cm})$ and weight of 100 seeds $(\mathrm{g})$. The third principal component consisted basically of the tuber quantitative traits and the biochemical properties. The major characters of interest in the three axes are the number of primary branches, number of secondary branches and days to flowering $(0.27,0.27,-0.27) ; 100$ seed weight and number of peduncles $(0.35,0.31)$ and also crude protein and tuber weight $(0.30,0.27)$, respectively.

\subsection{Genotypic, Phenotypic and Environmental Coefficients of Variation, Heritability Estimates and Genetic Advance of African Yam Bean Characters}

In Table 4 , values of the genotypic variance ( $\left.\delta^{2} \mathrm{~g}\right)$, phenotypic variance $\left(\delta^{2} \mathrm{p}\right)$, broad sense heritability estimate $\left(\mathrm{H}_{\mathrm{b}}\right)$ and Genetic advance (GA) of the 14 traits studied in two planting seasons, revealed number of pods per plant and yield per plant as recording highest genotypic variance (94.53 and 84.04). Also, the genotypic coefficients of variation (GCV) were also high for seed yield per plant and number of filled pods (74.07 and 70.15) respectively, accounting for the high heritability estimate of $98 \%$ recorded in the performance of pod and yield traits. However, GCV for days to maturity (31.30), number of seeds per plant (218.09) and number of peduncles per plant (37.28) were moderately high, compared to 
Table 3. Eigen vector of major traits of the first three principal components used in ordination.

\begin{tabular}{cccccc}
\hline \multicolumn{2}{c}{ Axis 1 } & \multicolumn{2}{c}{ Axis 2 } & \multicolumn{2}{c}{ Axis 3 } \\
\hline \multicolumn{2}{c}{ Character score } & \multicolumn{2}{c}{ Character score } & \multicolumn{2}{c}{ Character score } \\
\hline Vine length & 0.19 & No of peduncles & 0.31 & Tuber weight & 0.27 \\
Primary branches & 0.27 & Pods per peduncle & 0.19 & Crude protein & 0.30 \\
Secondary branches & 0.27 & Length of pod & 0.35 & Crude fiber & 0.25 \\
Internodal distance & 0.23 & Seeds per plant & 0.23 & Calcium & 0.25 \\
Days to flowering & -0.27 & 100 seed weight & -0.27 & Moisture content & 0.21 \\
\hline
\end{tabular}

Table 4. Genotypic, phenotypic, environmental coefficient of variation, heritability estimate and genetic advance of African yam bean characters.

\begin{tabular}{ccccccccc}
\hline Characters & $\delta^{2} \mathrm{~g}$ & $\delta^{2} \mathrm{p}$ & $\boldsymbol{\delta}^{2} \mathrm{e}$ & $\mathrm{GCV}(\%)$ & $\mathrm{PCV}(\%)$ & $\mathrm{ECV}(\%)$ & $\mathrm{H}$ & $\mathrm{GA}$ \\
Number of peduncles & 11.41 & 11.62 & 2.14 & 37.28 & 37.63 & 5.11 & 0.98 & 23.46 \\
Pods/plant & 84.04 & 85.65 & 16.18 & 49.66 & 50.14 & 6.89 & 0.98 & 172.91 \\
Filled pods/plant & 11.69 & 12.02 & 3.31 & 70.15 & 71.14 & 11.81 & 0.97 & 24.02 \\
Pod length & 10.98 & 13.08 & 2.10 & 13.94 & 15.22 & 6.10 & 0.84 & 22.63 \\
Seed/pod & 19.10 & 19.98 & 87.40 & 218.09 & 223.03 & 46.65 & 0.95 & 39.10 \\
100 seed weight & 13.63 & 15.23 & 1.6 & 19.07 & 20.16 & 6.53 & 0.90 & 28.24 \\
Vine length & 35.20 & 35.97 & 7.71 & 17.30 & 17.49 & 2.56 & 0.98 & 72.62 \\
Pri. Branches & 0.04 & 0.52 & 0.49 & 7.46 & 26.91 & 26.12 & 0.08 & 0.09 \\
Sec. branches & 0.76 & 1.66 & 0.90 & 13.11 & 19.38 & 14.27 & 0.46 & 1.57 \\
Internode & 10.25 & 16.89 & 6.64 & 25.88 & 33.22 & 20.83 & 0.61 & 21.22 \\
Seed/plant & 32.18 & 32.25 & 73.54 & 243.92 & 244.20 & 11.66 & 1.00 & 66.44 \\
Days to 50\% flowering & 11.25 & 14.39 & 3.15 & 2.98 & 3.37 & 1.58 & 0.78 & 23.12 \\
Days to maturity & 25.84 & 26.86 & 102.01 & 31.30 & 31.91 & 6.22 & 0.96 & 53.12 \\
Seed yield/plant & 94.53 & 9.61 & 16.07 & 74.07 & 74.70 & 9.66 & 0.98 & 19.40 \\
\hline
\end{tabular}

their respective genotypic variance values. This is responsible for the high values of the selection parameters. The high values of heritability estimate $(\mathrm{H})$ and genetic advance (GA) for these traits confer on them reliability for selection in a breeding programme that focuses on improving the seed yield of African yam bean. High values for $\mathrm{H}$ and GA indicates a genetic influence on the measured traits, rather than environmental influence.

\subsection{Genotype $\times$ Environment Analysis of 20 AYB Accessions Grown in Two Year Environments}

Table 5 presents the combined analysis of variance for twenty AYB genotypes grown in two year planting environments. It was revealed that the difference in the planting years had significant effect on the number of peduncles per plant (684.76), the number of pods per plant $(27,211.87)$, number of filled pods (680.63), 
Table 5. Genotype $\times$ Environment analysis of 20 AYB accessions grown in two year environments.

\begin{tabular}{|c|c|c|c|c|c|c|c|c|c|c|c|c|c|c|c|}
\hline \multicolumn{16}{|c|}{ Mean square } \\
\hline ò & 㟔 & 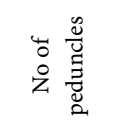 & 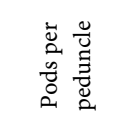 & 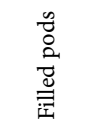 & 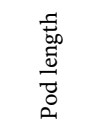 & 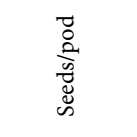 & 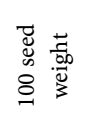 & 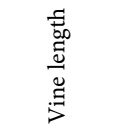 & 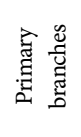 & 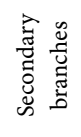 & 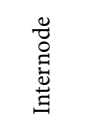 & 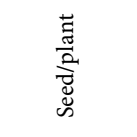 & 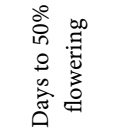 & 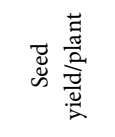 & 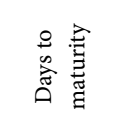 \\
\hline Year (Yr) & 1 & $684.76^{*}$ & $27,211.87^{* *}$ & $680.63^{*}$ & $532.90^{*}$ & $13,401.09^{* *}$ & 4.49 & $792.55^{*}$ & 3.31 & 8.98 & $\begin{array}{c}346.77 \\
*\end{array}$ & 127.45 & $1422.06^{* *}$ & 0.32 & $3871.06^{* *}$ \\
\hline $\operatorname{Rep} \times \mathrm{yr}$ & 6 & 12.97 & 232.86 & 16.31 & 8.42 & $9317.50^{* *}$ & 6.75 & 58.92 & 0.52 & 1.94 & 52.90 & $11,530.45^{* *}$ & 28.71 & 631.33 & $574.50^{*}$ \\
\hline Genotype & 19 & $1008.14^{* *}$ & $3045.16^{\star *}$ & $506.72^{*}$ & $120.88^{*}$ & $9235.91^{* *}$ & $89.93^{*}$ & $2099.58^{* *}$ & $1.18^{*}$ & $6.05^{*}$ & $69.68^{*}$ & $79,471.16^{*}$ & $92.34^{*}$ & $2117.78^{\star *}$ & $934.09 * *$ \\
\hline Gen $\times$ yr & 19 & 16.35 & $555.67^{* *}$ & $162.38^{*}$ & $11.80^{*}$ & $9735.62^{* *}$ & 2.24 & $243.66^{*}$ & 0.26 & 1.58 & 46.23 & $35,405.40^{*}$ & $71.08^{*}$ & $1401.32^{* *}$ & $619.69^{* *}$ \\
\hline Error & 114 & 5.29 & 11.89 & 6.74 & 2.96 & 96.76 & 3.19 & 8.74 & 0.26 & 0.87 & 7.25 & 65.46 & 4.01 & 14.15 & 24.52 \\
\hline
\end{tabular}

${ }^{*},{ }^{* *}=$ significant at 0.05 and 0.01 probability levels.

pod length (532.90), number of seeds per pod (13,401.09), vine length (792.55), internode distance (346.77), the number of days to $50 \%$ flowering (1422.06) and the number of days to pod maturity (3871.06). However, the effect of the interactions between the number of replications and the year was only significant on three of the characters measured, that is: the number of seeds per pod (9317.50), number of seeds per plant $(11,530.45)$ and the number of days taken by the pods to mature (574.50). The genotypic effect was significant for all the characters, whereas the effect of interactions between the genotypes and planting years was only significant for number of pods per peduncle (555.67), number of filled pods (162.38), pod length (11.80), number of seeds per pod (9735.62), vine length (243.66), number of seed per plant $(35,405.40)$, days to $50 \%$ flowering (71.08), seed yield per plant (1401.32) and the number of days required by the pods to attain physiological maturity.

\subsection{Root Form, Number of Tubers, Weight of Tuber and Proximate Analysis of African Yam Bean}

Root forms, number of tubers produced, tuber weight and the proximate analyses of the tubers' dry matter, as presented in Table 6 showed that only five accessions (G2, G4, G47, G49 and G50) produced tuber, while accessions G5, G15, G31, G32 and G33 produced root nodules. The highest number of tubers were observed to be produced by G49 (4 tubers), with G4 producing the least (1 tuber). However, average tuber weight is highest for G47 (185 g), whereas G2 has the least average tuber weight of $56.6 \mathrm{~g}$. G47 is seen to have the highest Iron content $(0.9 \mathrm{mg} / \mathrm{kg})$. While the crude fibre content of $6.25 \%$ was highest, produced by G4, crude protein and Calcium contents were relatively higher in G47 (16.88\% and $0.64 \%$ ) as compared to what was obtained in G2, revealing the least contents of Iron $(0.38 \mathrm{mg} / \mathrm{kg})$, crude protein, Crude fibre and Calcium at $8.69 \%$, $4.86 \%$ and $0.54 \%$ respectively. Conversely, the measured nutritional and mineral parameters (i.e. $\mathrm{CP}, \mathrm{CF}, \mathrm{Ca}$ and $\mathrm{Fe}$ ) were highest in the nodule root form produced by G32, having the values $17.81 \%, 7.4 \%, 0.71 \%$ and $1.06 \mathrm{mg} / \mathrm{kg}$ respectively. 
Table 6. Root form, number of tubers, weight of tuber and proximate analysis of African yam bean.

\begin{tabular}{cccccccc}
\hline Genotype/Trait & Root form & $\begin{array}{c}\text { Number } \\
\text { of tubers }\end{array}$ & $\begin{array}{c}\text { Ave. tuber } \\
\text { weight(g) }\end{array}$ & \% CP & \% CF & \% Ca & Fe (mg/kg) \\
\hline G2 & Tuber & 2 & 56.6 & 8.69 & 4.86 & 0.54 & 0.38 \\
G4 & Tuber & 1 & 88.5 & 13.56 & 6.25 & 0.61 & 0.72 \\
G5 & Nodule & -- & 174.8 & 11.5 & 6.5 & 0.6 & 1 \\
G15 & Nodule & -- & 349.7 & 13.75 & 6.3 & 0.63 & 0.68 \\
G31 & Nodule & -- & 198.8 & 12.83 & 4.88 & 0.62 & 0.36 \\
G32 & Nodule & -- & 477.6 & 17.81 & 7.4 & 0.71 & 1.06 \\
G33 & Nodule & -- & 153.2 & 11.25 & 5.9 & 0.57 & 0.57 \\
G47 & Tuber & 3 & 185 & 16.88 & 6.1 & 0.64 & 0.94 \\
G49 & Tuber & 4 & 161.2 & 13 & 5.98 & 0.55 & 0.8 \\
G50 & Tuber & 2 & 84.8 & 9.25 & 5 & 0.6 & 0.41 \\
\hline
\end{tabular}

\section{Discussion}

The significantly wide variations among AYB accessions as reflected by the characters that were measured indicated a rich genetic diversity useful for varietal improvement of the plant. In the eight main principal component axes, the first six axes explained above $70 \%$ of total variation in the accessions. Consequently, the use of different measurement techniques can be appropriately used for accession grouping (Bauer et al. [20]). Highest genetic distance was observed between G1 and G25 accessions. According to Aremu et al. [18]; Brown-Guedira et al. [21]; Rahim et al. [22] who showed that the hybrids of accessions with maximum genetic distance resulted in high yield, the cross between these accessions could be used in breeding programs to achieve maximum heterosis in cowpea, soybean and mungbean respectively. Minimum distance was between accessions G50 and G7, which can be explored for backcross breeding programs. Evaluation of genetic diversity can be useful for the selection of the most desirable and efficient accessions. Accordingly, if such effort results in the reduction of diversity, production of plants with higher uniformity may guarantee the production of enough food for the world's increasing population. The highly significant genotypic effect and high heritability values for all the characters, except number of seeds per pod, internodal distance and number of days to pod maturity, is suggestive of the genetic potential in explaining these traits for African yam bean improvement.

\section{Conclusions}

Considering the eight main principal component axes, the first six axes explained above $70 \%$ of total variation in the accessions. Principal component analysis and cluster analysis allowed a natural grouping of the African yam bean 
accessions, consequently, the use of different measurement techniques can be appropriately used for accession grouping (Bauer et al. [20]). Highest genetic distance was observed between G1 and G25 accessions. According to Aremu et al. ([18]), Brown-Guedira et al. ([21]), Rahim et al. ([22]) who showed that the hybrids of accessions with maximum genetic distance resulted in high yield, the cross between these accessions could be used in breeding programs to achieve maximum heterosis in cowpea, soybean and mungbean respectively.

High heritability of vine length, number of pods per plant and seed yield per plant indicated that these traits were under genetic control (Mohammadi et al. [23]). Thus, to improve these traits, breeding programs without progeny testing could be used. This finding is supported by Ojo and Amanze ([24]), who reported high heritability in cowpea. Number of primary and secondary branches and also, the internodal distance exhibited lowest heritability and are under environmental control. Improvement of these traits therefore could be achieved through progeny testing. Heritability estimates are usually unique to the population under study, the growing conditions and the experimental design used (Bergman et al. [25]).

\section{Conflicts of Interest}

The authors declare no conflicts of interest regarding the publication of this paper.

\section{References}

[1] Okigbo, B.N. (1973) Introducing the Yam Bean. Proceedings of the 1st IITA Grain Legume Improvement Workshop, IITA, Ibadan, Nigeria, 29th October-2nd November 1973.

[2] Genetic Resources Information Network (2009) Taxonomy for Plants. http://www.ars-grin.gov/cgi-bin/npgs/html/taxon.pl?35250\#dist

[3] Dalziel, J.M. (1995) The Useful Plants of West Tropical Africa. Crown Agents for the Colonies, London, 612.

[4] Ene-Obong, E.E. and Okoye, F.I. (1992) Interrelationships between Yield and Yield Components in African Yam Bean. Beitrage zur tropischen Landwirtschaft und Veterinarmedizin, 30, 283-290.

[5] Dukes, J.A. (1981) Handbook of Legumes of World Economic Importance. Plenum Press, New York, 220-222. https://doi.org/10.1007/978-1-4684-8151-8

[6] Anochili, B.C. (1984) Tropical Agricultural Handbook. Food Crop Production. Macmillan Publishers, London, 48-50.

[7] Ajibade, S.R., Balogun, M.O., Afolabi, O.O., Ajomale, K.O. and Fasoyiro, S.B. (2005) Genetic Variation in Nutritive and Anti-Nutritive Content of African Yam Bean (Sphenostylis stenocarpa). Tropical Science, 45, 144-148. https://doi.org/10.1002/ts.14

[8] Saka, J.O., Ajibade, S.R., Adeniyan, O.N., Olowoyo, R.B. and Ogunbodede, B.A. (2004) Survey of Underutilized Grain Legume Production Systems in the Southwest Agricultural Zone of Nigeria. Journal of Agricultural and Food Information, 6, 93-108. https://doi.org/10.1300/J108v06n02_08 
[9] Ekpo, A.S. (2006) Changes in Amino Acid Composition of African Yam Beans (Sphenostylis stenocarpa) and African Locust Beans (Parkia filicoida) on Cooking. Pakistan Journal of Nutrition, 5, 254-256. https://doi.org/10.3923/pjn.2006.254.256

[10] Nwokolo, E.A. (1996) The Need to Increase Consumption of Pulses in the Developing World. In: Nwokolo, E. and Smart, J., (Eds.), Food and Feed from Legumes and Oilseeds, Chapman and Hall, London, 3-11.

https://doi.org/10.1007/978-1-4613-0433-3_1

[11] National Research Council-NRC (2007) Lost Crops of Africa: Vol II: Vegetables and Yam Bean Development. Security and Cooperation Policy and Global Affairs (DSC), Washington DC, 322-344.

[12] Amoatey, H.M. (2000) The African Yam Bean: A Neglected Crop in Ghana. Biotechnology and Nuclear Agriculture Research Institute Journal, 6, 74-77.

[13] Uguru, M.I. and Madukaife, S.O. (2001) Studies on the Variability in Agronomic and Nutritive Characteristics of African Yam Bean. Plant Products Research Journal, 8, 10-19.

[14] Fu, Y.B. (2006) Impact of Plant Breeding on Genetic Diversity of Agricultural Crops: Searching for Molecular Evidence. Plant Genet Resource, 4, 71-78. https://doi.org/10.1079/PGR2006116

[15] Moyib, O.K. (2008) Genetic Variation within a Collection of Nigerian Accessions of African Yam Bean Revealed by RAPD Primers. African Journal of Biotechnology, 7, 1839-1846. https://doi.org/10.5897/AJB08.117

[16] Wiley, E.O. (1981) Phylogenetics: The Theory and Practice of Phylogenetics and Systematics. John Wiley, New York.

[17] Mohammadi, S.A. and Prasanna, B.M. (2003) Analysis of Genetic Diversity in Crop Plants-Salient Statistical Tools and Considerations. Crop Science, 43, 1235-1248. https://doi.org/10.2135/cropsci2003.1235

[18] Aremu, C.O., Ariyo, O.J. and Adewale, B.D. (2007) Assessment of Selection Techniques in Genotype $\times$ Environment Interaction in Cowpea. Journal of Agricultural Research, 2, 352-355.

[19] AOAC (2005) Official Methods of Analysis. Chapter 45, Association of Official Analytical Chemists, Washington DC, 9.

[20] Bauer, I., Drinic, S.M., Drinic, G. and Micic, D.I. (2007) Assessing Temporal Changes in Genetic Diversity of Maize Hybrids Using RAPD Markers. Cereal Research Communications, 35, 1563-1571. https://doi.org/10.1556/CRC.35.2007.4.3

[21] Brown-Guedira, G.L., Thompson, J.A., Nelson, R.L. and Warburton, M.L. (2000) Evaluation of Genetic Diversity of Soybean Introductions and North American Ancestors Using RAPD and SSR Markers. Crop Science, 40, 815-823. https://doi.org/10.2135/cropsci2000.403815x

[22] Rahim, M.A., Mia, A.A., Mahmud, F., Zeba, N. and Afrin, K. (2010) Genetic Variability, Character Association and Genetic Divergence in Mungbean (Vigna radiate L. Wilczek). Plant Omics, 3, 1-6.

[23] Mohammadi, A.A., Saeidi, G. and Arzani, A. (2010) Genetic Analysis of Some Agronomic Traits in Flax (Linum usitatissimum L.). Australian Journal of Crop Science, 4, 343-352.

[24] Ojo, D.K. and Amanze, C.O. (2001) Prediction of Grain Yield through Heritability and Genetic Advance of Yield Parameters in Soybean. Nigeria Journal of Ecology, 3, 10-13. 
[25] Bergman, C.J., Gualberto, D.G., Campbell, K.G., Sorrells, M.E. and Finney, P.L. (1998) Genotype and Environment Effects on Wheat Quality Traits in a Population Derived from a Soft by Hard Cross. Cereal Chemistry, 75, 729-737.

https://doi.org/10.1094/CCHEM.1998.75.5.729 